\title{
Maize intercropped with Urochloa ruziziensis under no-tillage system ${ }^{1}$
}

\author{
Renata Fernandes de Queiroz ${ }^{2}$, Carlos Alessandro Chioderoli ${ }^{3}$, \\ Carlos Eduardo Angeli Furlani ${ }^{2}$, Henrique Vinícius de Holanda ${ }^{2}$, Cristiano Zerbato ${ }^{2}$
}

\section{ABSTRACT}

The no-tillage system is a conservation practice that seeks greater sustainability of the production system and can be replicated in large land areas. Maize intercropped with forages of the Urochloa genus has proven to be profitable and suitable for targeting both the straw and grain production. This study aimed at evaluating maize yield and cover plants, using different maize row spacings and forage seeding methods, under a no-tillage system. A randomized blocks design, in a $2 \times 3+2$ factorial scheme, with four replications, was used. The treatments consisted of two maize row spacings $(0.45 \mathrm{~m}$ and $0.90 \mathrm{~m})$ intercropped with Urochloa ruziziensis, using three different methods (Urochloa sown in the row, Urochloa sown by hauling soon after maize was sown and Urochloa sown during the maize V4 growth stage) + controls (only maize at two spacings). The intercropping between maize spaced $0.90 \mathrm{~m}$ with Urochloa ruziziensis in the sowing row provided better grain yield results without interfering with the Urochloa dry matter production.

KEY-WORDS: Zea mays L.; spatial arrangement; brachiaria; crop-livestock integration.

\section{INTRODUCTION}

Crop-livestock integrated systems have economic and environmental advantages, such as higher income per area, greater diversification of activities, less economic risks and lower production costs (Balbinot Junior et al. 2009). Therefore, they play an important role in the sustainability of the Brazilian livestock model.

Maize (Zea mays L.) stands out in these integration systems (Alvarenga et al. 2006), since it

\section{RESUMO}

\section{Consórcio de milho com \\ Urochloa ruziziensis sob plantio direto}

O sistema plantio direto é uma prática conservacionista que visa a uma maior sustentabilidade do sistema produtivo, podendo ser reproduzida em grandes extensões de área. $\mathrm{O}$ cultivo de milho em consórcio com forrageiras do gênero Urochloa vem se mostrando rentável e compatível, visando tanto à produção de palhada como à de grãos. Objetivou-se avaliar a produção de milho e de plantas de cobertura vegetal, em diferentes espaçamentos do milho e modalidades de semeadura da forrageira, no sistema plantio direto. Utilizou-se delineamento experimental em blocos casualizados, em esquema fatorial $2 \times 3+2$, com 4 repetições. Os tratamentos foram constituídos por dois espaçamentos da cultura do milho $(0,45 \mathrm{~m}$ e $0,90 \mathrm{~m}$ ) e três modalidades de consórcio de Urochloa ruziziensis com milho (Urochloa semeada na linha; Urochloa semeada a lanço junto à semeadura do milho e Urochloa semeada a lanço no estádio $\mathrm{V}_{4}$ do milho) + testemunhas (milho solteiro em dois espaçamentos). O consórcio de milho $(0,90 \mathrm{~m})$ com Urochloa ruziziensis na linha de semeadura proporcionou melhores resultados de produção de grãos, sem interferir na produção de massa seca da planta de Urochloa.

PALAVRAS-CHAVE: Zea mays L.; arranjo espacial; braquiária; integração lavoura-pecuária.

is the second largest crop produced in Brazil, second only to soybean. In the $2015 / 2016$ harvest year, more than 15 million hectares were planted with maize, using different cropping systems, whether or not conservationist, totaling more than 83 million tons of grains (Conab 2016).

The maize spatial arrangement is one of the most important agronomic aspects influencing crop performance and yield in the crop-livestock integrated systems. Plant density interferes with the grain yield potential, dry matter and phytotechnical

1. Manuscript received in Mar./2016 and accepted for publication in Aug./2016 (http://dx.doi.org/10.1590/1983-40632016v4640464).

2. Universidade Estadual Paulista "Júlio de Mesquita Filho", Faculdade de Ciências Agrárias e Veterinárias, Departamento de Engenharia Rural, Jaboticabal, SP, Brazil.E-mails: renatafq@gmail.com, furlani@fcav.unesp.br, henriquevholanda@hotmail.com,zerbato@fcav.unesp.br.

3. Universidade Federal do Ceará, Centro de Ciências Agrárias, Departamento de Engenharia Agrícola, Fortaleza, CE, Brazil. E-mail: ca.chioderoli@ufc.br. 
characteristics of maize, because they change the availability of solar radiation inside the canopy (Costa et al. 2005, Pereira Filho et al. 2008).

In recent decades, the introduction of more productive hybrids tolerant to water and nutritional stress; the use of technologies to control weeds, pests and diseases; and the expanding use of fertilizers and soil correctives (Argenta et al. 2001, Stacciarini et al. 2010) have allowed higher plant population densities and smaller maize row spacing. Ribas et al. (2013) demonstrated that the reduced maize row spacing $(0.45 \mathrm{~m})$ in single crop systems resulted in smaller plants. However, grain yield is higher, when compared to higher maize row spacing $(0.90 \mathrm{~m})$. The reduced spacing between rows improved the phytotechnical characteristics of the plants and decreased the interference of weeds. However, when rows are close together, there is a lower incidence of light, and the plants tend to allocate greater amounts of reserves for the development of roots, hindering the development of smaller plants (Balbinot Junior \& Fleck 2004).

Among forages, Brachiaria grasses have been highlighted as an alternative for intercropping in crop-livestock integrated systems, since, depending on the spacing between rows, they cause little or no interference on grain yield (Freitas et al. 2013). Borghi \& Crusciol (2007) investigated the intercropping of maize with Urochloa brizantha, using four sowing methods and two spacing distances, and found that the reduced spacing $(0.45 \mathrm{~m})$ interfered with maize yield, when the forage was sown in the line/row and between the rows. Freitas et al. (2013) showed that increasing the maize density could decrease forage production, and recommended higher densities only when there is no water restriction. Correia et al. (2013) worked with Urochloa ruziziensis and showed that forage seeding in row or by hauling, at 22 days after maize sowing, had no negative effect on grain yield, when compared to the maize single crop. Therefore, when implementing a maize crop, the best spatial arrangement and forage sowing method should be defined based on the objectives of the production system, whether it aims at production of straw, straw and forage or fodder only (Chioderoli et al. 2010, Borghi et al. 2013).

This study aimed at evaluating two maize spatial arrangements and three Urochloa ruziziensis sowing methods, under a no-tillage system.

\section{MATERIAL AND METHODS}

The study was conducted in the experimental area of the Universidade Estadual Paulista "Júlio

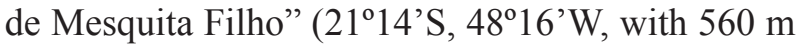
mean altitude and $4 \%$ slope), in Jaboticabal, São Paulo State, Brazil. The experimental area has been cultivated under the no-tillage system for over ten years. The climate, according to the Köppen-Geiger classification, is Aw, tropical humid, with rainy summer and dry winter. The rainfall and temperature data during the experiment are shown in Figure 1. The soil of the experimental area is classified as a typical Oxisoil, clayey, A moderate, kaolinitic-oxidic (LVef) (Andrioli \& Centurion 1999), with the following particle distribution: $200 \mathrm{~g} \mathrm{~kg}^{-1}$ of sand, $290 \mathrm{~g} \mathrm{~kg}^{-1}$ of silt and $510 \mathrm{~g} \mathrm{~kg}^{-1}$ of clay.

Two distances between maize rows were tested $(0.45 \mathrm{~m}$ and $0.9 \mathrm{~m})$, as well as three Urochloa ruziziensis (forage) sowing methods. For the $0.45 \mathrm{~m}$ distance, the treatments were as it follows: E1M1forage sown in the maize row; E1M2 - forage sown by hauling in the maize row; E1M3 - forage sown by hauling when the maize reached the V4 stage. For the $0.90 \mathrm{~m}$ distance, the treatments were: E2M1forage sown in the maize row; E2M2 - forage sown by hauling in the maize row; E2M3 - forage sown by hauling when the maize reached the V4 stage. The control treatments were: T1 - maize only, spaced $0.45 \mathrm{~m}$ between rows; $\mathrm{T} 2$ - maize only, spaced $0.90 \mathrm{~m}$ between rows.

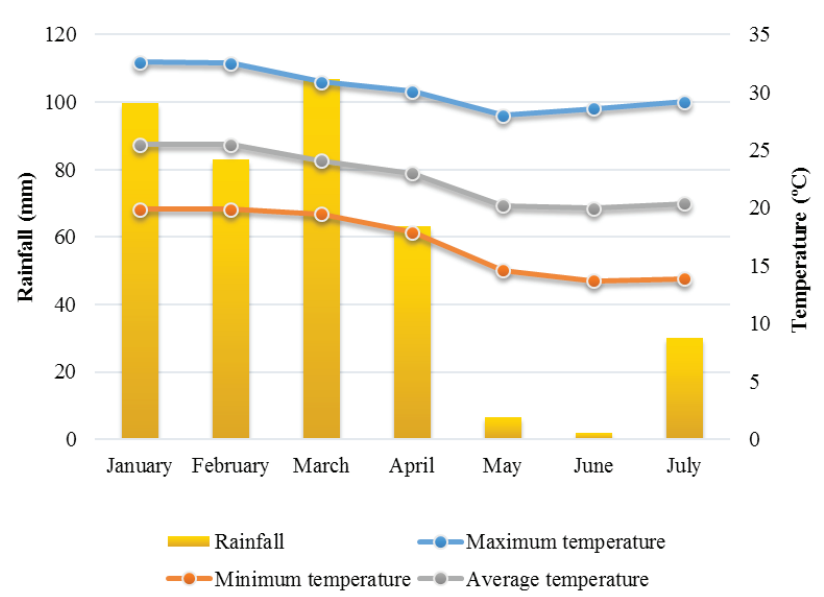

Figure 1. Rainfall, maximum, minimum and average temperature, during the experimental period, in the 2014 harvest, in Jaboticabal. Source: Universidade Estadual Paulista "Júlio de Mesquita Filho". 
The experimental plots were $4.0 \mathrm{~m}$ wide and $15.0 \mathrm{~m}$ long, spaced $5 \mathrm{~m}$ apart. Thirty-two experimental units were formed, with seven and four maize rows for the $0.45 \mathrm{~m}$ and $0.90 \mathrm{~m}$ row spacings, respectively. The plot useful areas corresponded to two and three $5 \mathrm{~m}$ long central rows, respectively for the $0.90 \mathrm{~m}$ and $0.45 \mathrm{~m}$ row spacings. A randomized blocks design, in a $2 \times 3+2$ factorial scheme, with four replications, was used.

The trial lasted from January to June 2014. The Powercore maize hybrid 2B710PW cultivar was planted, targeting a population of 60,000 plants ha $^{-1}$, with row spacings of $0.45 \mathrm{~m}$ and $0.90 \mathrm{~m}$. The corresponding sowing densities were 2.7 seeds $\mathrm{m}^{-1}$ and 5.4 seeds $\mathrm{m}^{-1}$, respectively, considering the slippage of the seeding machine, germination, purity and survival rate of seeds. Certified Urochloa ruziziensis seeds (11.5 $\mathrm{kg} \mathrm{ha}^{-1}$ and $60 \%$ crop value) were intercropped. Basic fertilization used $300 \mathrm{~kg} \mathrm{ha}^{-1}$ of NPK (04-20-20). Complementary topdressing was performed when maize reached the V4 stage, using $120 \mathrm{~kg} \mathrm{ha}^{-1}$ of potassium chloride and $300 \mathrm{~kg} \mathrm{ha}^{-1}$ of urea, as determined by the soil chemical analysis (Table 1) and fertilizer recommendation for maize crops with yields above $8 \mathrm{t} \mathrm{ha}^{-1}$ (Embrapa 2006).

The mechanized seeding processes used one tractor ( 4 x 2 TDA), with $91.9 \mathrm{~kW}(125 \mathrm{cv})$ maximum power and 1,950 rpm, working in L3, at $4.0 \mathrm{~km} \mathrm{~h}^{-1}$, and $7,000 \mathrm{~kg}$ mass (40\% front and $60 \%$ rear), calculated for average operations, $56 \mathrm{~kg} \mathrm{cv}^{-1}, 14.9-24 \mathrm{R} 1$ and 18.4-34 R1 front and rear tires, $18(124 \mathrm{kPa})$ and $22 \mathrm{psi}(152 \mathrm{kPa})$, respectively, and $0.415 \mathrm{~m}$ drawbar height. The drag seeder used had pneumatic disc seed metering, helical fertilizer distributor, set for direct sowing with 18 " front blade, rod-type trencher working at $0.14 \mathrm{~m}$ depth and set to deposit the fertilizer at $0.08 \mathrm{~m}$, staggered 15 " double discs to deposit seeds at $0.05 \mathrm{~m}$ deep, and V-shaped compacting wheels, set to seven rows spaced $0.45 \mathrm{~m}$ and four rows spaced $0.90 \mathrm{~m}$ for maize planting.

The final plant population was determined by counting the number of plants present in the useful plot area before harvest, and the values were extrapolated for plants ha-1. Grain yield was determined by harvesting the ears from each useful plot area and threshing using a mechanical threshing. Grains were separated, weighed and corrected for $13 \%$ wet basis (Brasil 1992), using the following equation:

$$
\mathrm{P}=\mathrm{I} \times \frac{100-\mathrm{U}}{100-13}
$$

where $\mathrm{P}=$ grain mass with $13 \%$ moisture $(\mathrm{kg}) ; \mathrm{U}=$ actual water content of grains (\%); I = initial sample weight. The 1,000-grain weight was determined by quantifying the mass corrected to $13 \%$ moisture content of 800 fold samples chosen at random (Brasil 1992).

All maize plants from the useful plot area were weighed, subtracting the weight of the grain after threshing, to obtain the mass of green straw matter. A $0.25 \mathrm{~m}^{2}$ iron frame was thrown randomly in the field and all forage contained inside the iron frame was collected and packaged in paper bags. Two sub-samples were prepared per plot for the hauling treatments. For the forage sown in row, $2 \mathrm{~m}$ were collected from two rows of the useful plot area. The total dry matter was determined by adding the maize and forage dry matter. The plant matter was weighed and the samples were taken to a forced air circulation oven at $65^{\circ} \mathrm{C}$, for $48 \mathrm{~h}$, to constant weight, to determine straw dry matter per hectare.

All data were submitted to coefficient of skewness and kurtosis analyses, to verify the data normality. The variables analyzed displayed normal distribution, with skewness and kurtosis values within the -2 and 2 range (Montgomery 2004). Maize agronomic characteristics and coverage were evaluated in a $2 \times 3$ factorial scheme, taking into account the sowing spacing and arrangement. The control and treatments were compared using the $2 \times 3+1$ factorial scheme, comparing all treatments with each control distinctly. The data were submitted to the F test and, when necessary, the Tukey test was applied $(\mathrm{p}<0.05)$ to compare the means. The factorial was compared to the control (maize only) by the Dunnett test $(\mathrm{p}<0.05)$.

Table 1. Mean values of soil chemical parameters evaluated in the $0.0-0.10 \mathrm{~m}$ depth layer, in the experimental area.

\begin{tabular}{|c|c|c|c|c|c|c|c|c|c|c|}
\hline \multirow{2}{*}{ Season } & $\mathrm{OM}$ & & $\mathrm{P}$ & $\mathrm{K}$ & $\mathrm{Ca}$ & $\mathrm{Mg}$ & $\mathrm{H}+\mathrm{Al}$ & SB & $\mathrm{T}$ & \multirow{2}{*}{$\mathrm{V} \%$} \\
\hline & $\mathrm{g} \mathrm{dm}^{-3}$ & $(\mathrm{Cal} \mathrm{Cl})_{2}$ & \multicolumn{2}{|c|}{$-\mathrm{mg} \mathrm{dm}^{-3}$} & 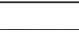 & 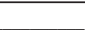 & $\mathrm{nol} \mathrm{dm}{ }^{-3}$ & & - & \\
\hline Before sowing maize & 25.8 & 5.6 & 44.4 & 144.3 & 47.6 & 18.92 & 24.4 & 70.2 & 94.6 & 73 \\
\hline
\end{tabular}




\section{RESULTS AND DISCUSSION}

The spacing between rows had significant effect on final maize population, 1,000-grain weight, grain yield, maize dry matter and total dry matter (Table 2). The $0.45 \mathrm{~m}$ row spacing resulted in higher plant density and dry matter, regardless of forage seeding method. On the other hand, higher 1,000-grain weight, grain yield and total dry matter were obtained for the $0.90 \mathrm{~m}$ row spacing.

The sowing density per meter directly affects seed distribution and plant density (Dias et al. 2009), because, to maintain the same population density per area, when spacing is greater (e.g. $0.90 \mathrm{~m}$ ), a larger number of plants should be planted per row. However, this densification causes failures in the longitudinal seed distribution, reducing the plant population effectively established (Schimandeiro et al. 2006). Also, the resulting spatial arrangement for the $0.90 \mathrm{~m}$ distance may have promoted greater intraspecific competition in maize. These factors explain the lower density, maize and total (maize + Urochloa) dry matter, for the $0.90 \mathrm{~m}$ spacing (Table 2).

Borghi et al. (2008) evaluated the effect of spacing between maize rows and Urochloa brizantha sowing methods and reported higher maize dry matter for the $0.45 \mathrm{~m}$ spacing, when forage was sown simultaneously between rows. However, the results reported in this study showed that both spacings produced enough dry matter to maintain the no-tillage system, which, according to Embrapa (2010), should have values of about $6,000 \mathrm{~kg} \mathrm{ha}^{-1}$.
The results reported are above the national average, which is approximately $4,500 \mathrm{~kg} \mathrm{ha}^{-1}$ for grain yield (Embrapa 2012), in both spacings and sowing methods evaluated. Moreover, 1,000-grain weight and grain yield were higher for the $0.90 \mathrm{~m}$ spacing (Table 2). The significant difference observed for the 1,000-grain weight variable shows that the environmental variables, soil, water and sunlight were used more efficiently when spacing was $0.90 \mathrm{~m}$. This result may be associated with the lower final plant density, which enabled lower intraspecific competition between maize plants, corroborating the lower 1,000-grain weight obtained when maize density increased.

Maize grain yield was higher for the $0.90 \mathrm{~m}$ spacing, even though plant density was lower. The sowing method did not affect grain yield. This result may be associated with higher 1,000-grain weight in the $0.90 \mathrm{~m}$ spacing, when compared to the 0.45 spacing, and the fact that maize can produce more than one ear per plant.

According to Ritchie et al. (2003), at lower densities, maize plants tend to be more prolific. Similar maize yields and 1,000-grain weights have been reported by Torres et al. (2013), for the $0.90 \mathrm{~m}$ and $0.45 \mathrm{~m}$ spacings. Calonego et al. (2011) studied different maize densities and different spacings, and observed that yield did not differ significantly for 45,000 plants $\mathrm{ha}^{-1}$ and 60,000 plants $\mathrm{ha}^{-1}$ densities, but the results were better for the $0.90 \mathrm{~m}$ spacing. Borghi \& Crusciol (2007) investigated maize intercropped with other species of the Urochloa

Table 2. Mean values for maize density, 1,000-grain weight, grain yield, maize and Urochloa ruziziensis dry matter and total dry matter.

\begin{tabular}{|c|c|c|c|c|c|c|c|}
\hline \multirow{3}{*}{ Variable } & & \multirow{2}{*}{$\begin{array}{c}\text { Plant } \\
\text { density }\end{array}$} & \multirow{2}{*}{$\begin{array}{c}\text { 1,000-grain } \\
\text { weigth }\end{array}$} & \multirow{2}{*}{$\begin{array}{l}\text { Grain } \\
\text { yield }\end{array}$} & \multicolumn{3}{|c|}{ Dry matter } \\
\hline & & & & & Maize & Urochloa & Total \\
\hline & & plants $\mathrm{ha}^{-1}$ & $\mathrm{~kg}$ & & $\mathrm{~kg}$ & & \\
\hline \multirow{2}{*}{ Spacing $(E)$} & E1 & $55,574.07 \mathrm{a}$ & $0.26 \mathrm{~b}$ & $9,921.86 \mathrm{~b}$ & $8,995.30 \mathrm{a}$ & $1,713.93$ & $11,143.57 \mathrm{a}$ \\
\hline & E2 & $42,592.59 \mathrm{~b}$ & $0.29 \mathrm{a}$ & $12,037.36 \mathrm{a}$ & $5,759.95 \mathrm{~b}$ & $2,008.60$ & $8,057.15 \mathrm{~b}$ \\
\hline \multirow{3}{*}{ Sowing method (M) } & M1 & $47,083.33$ & 0.27 & $10,782.18$ & $8,092.54$ & $1,925.87$ & $10,120.64$ \\
\hline & M2 & $47,833.33$ & 0.27 & $10,872.32$ & $6,698.58$ & $2,058.54$ & $9,333.13$ \\
\hline & M3 & $52,333.33$ & 0.27 & $11,284.34$ & $7,341.75$ & $1,599.39$ & $9,347.30$ \\
\hline \multirow{3}{*}{ F value } & $\mathrm{E}$ & $22.815^{*}$ & $12.587 *$ & $9.401^{*}$ & $38.42 *$ & $2.45^{\mathrm{ns}}$ & $31.0^{*}$ \\
\hline & M & $1.455^{\mathrm{ns}}$ & $0.005^{\mathrm{ns}}$ & $0.201^{\mathrm{ns}}$ & $2.38^{\mathrm{ns}}$ & $2.10^{\mathrm{ns}}$ & $0.88^{\mathrm{ns}}$ \\
\hline & $\mathrm{E} \times \mathrm{M}$ & $0.915^{\mathrm{ns}}$ & $2.042^{\mathrm{ns}}$ & $0.342^{\mathrm{ns}}$ & $0.18^{\mathrm{ns}}$ & $1.50^{\mathrm{ns}}$ & $0.08^{\mathrm{ns}}$ \\
\hline \multirow{2}{*}{ LSD } & $\mathrm{E}$ & $5,792.78$ & 0.015 & $1,470.60$ & $1,112.55$ & 401.23 & $1,181.51$ \\
\hline & M & $8,650.48$ & 0.023 & $2,196.08$ & $1,661.39$ & 599.17 & $1,744.38$ \\
\hline CV (\%) & & 13.56 & 6.54 & 15.39 & 17.33 & 24.77 & 14.4 \\
\hline
\end{tabular}


generic taxon in different spacings and reported that grain yield is lower for the $0.45 \mathrm{~m}$ spacing, when intercropped with Urochloa. The dry matter was higher for the $0.45 \mathrm{~m}$ spacing, if compared to the $0.90 \mathrm{~m}$ spacing, what can be explained by the higher plant density at the $0.45 \mathrm{~m}$ spacing, which results from the more uniform longitudinal distribution, with higher percentages of normal spacing and no influence of the Urochloa seeding method on the maize dry matter content. Sangoi et al. (2005) reported that the maize dry matter decreases as plant density increases, unlike the results of this study, where the dry matter increased with the $0.45 \mathrm{~m}$ spacing, even though the maize population density is increased. The total dry matter data demonstrated that higher values of dry matter were observed for maize spaced at $0.45 \mathrm{~m}$.

The maize spacing and forage sowing methods did not affect the dry matter accumulation of Urochloa ruziziensis $(\mathrm{p}>0.05)$. The dry matter production observed in this experiment was below the $4,000 \mathrm{~kg} \mathrm{ha}^{-1}$ of dry matter reported by Costa et al. (2012), for Urochloa ruziziensis and maize intercropping. However, Batista et al. (2011) reported Urochloa ruziziensis dry matter of about $1,000 \mathrm{~kg} \mathrm{ha}^{-1}$, at the maize physiological maturity, for regions of the São Paulo State.

The maize dry matter content was not significantly different for the control (maize only), if compared to the maize and forage intercropping with both spacings, and Urochloa ruziziensis sowing methods, even when forage was sown by hauling at the V4 maize stage, where a better result was expected for the maize crop. The maize yield showed that, for the conditions of this study, the $0.90 \mathrm{~m}$ spacing between maize and Urochloa ruziziensis intercropped in the maize row is the most appropriate, taking into account the higher grain yield for the $0.90 \mathrm{~m}$ and the operational factors during the Urochloa seeding. Even if maize yield was not significantly different for the Urochloa sowing methods, sowing forage on maize rows reduces the costs and impacts caused by the use of agricultural equipment, thus reducing the mechanized processes. For seeding on rows, the Urochloa seeds are mixed with fertilizer and deposited in the soil simultaneously with maize, without changing the number of mechanized processes, unlike seeding by hauling, when another mechanical process is required, changing the traffic in the area and increasing power consumption.

Grain yield, 1,000-grain weight and maize dry matter were not significantly different between treatments (spacing between rows and forage seeding methods), if compared to the controls, maize only, spaced at $0.45 \mathrm{~m}$ (T1) and $0.90 \mathrm{~m}$ (T2). However, the plant population density differed between treatments and controls, maize only, spaced at $0.45 \mathrm{~m}$ (Table 3) and $0.90 \mathrm{~m}$ (Table 4).

The intercropping systems between maize and Urochloa ruziziensis did not affect the final plant density at the $0.45 \mathrm{~m}$ spacing, since productivity variables were similar for both crops, intercropping and control (T1). Likewise, higher plant density was recorded for treatments at the

Table 3. Mean value for final density, 1,000-grain weight and grain yield, when compared to the control at $0.45 \mathrm{~m}$ spacing.

\begin{tabular}{|c|c|c|c|c|c|}
\hline \multicolumn{2}{|c|}{ Variable } & \multirow{2}{*}{$\begin{array}{c}\begin{array}{c}\text { Final plant } \\
\text { density }\end{array} \\
\text { plants ha }{ }^{-1}\end{array}$} & \multirow{2}{*}{$\begin{array}{c}\begin{array}{c}\text { 1,000-grain } \\
\text { weight }\end{array} \\
\mathrm{kg}\end{array}$} & $\begin{array}{c}\text { Grain } \\
\text { yield }\end{array}$ & \multirow{2}{*}{$\begin{array}{c}\text { Maize } \\
\text { dry matter } \\
\end{array}$} \\
\hline Spacing & Method & & & $\mathrm{kg} \mathrm{ha}^{-1}$ & \\
\hline E1 & M1 & $51,111.11^{\mathrm{ns}}$ & 267.90 & $9,485.46$ & $9,657.37$ \\
\hline E1 & M2 & $54,833.33^{\mathrm{ns}}$ & 270.59 & $9,652.31$ & $8,157.00$ \\
\hline E1 & M3 & $60,777.77^{\mathrm{ns}}$ & 254.29 & $10,627.82$ & $9,171.54$ \\
\hline E2 & M1 & $43,055.55^{*}$ & 286.56 & $12,078.90$ & $6,527.72$ \\
\hline E2 & M2 & $40,833.33^{*}$ & 283.58 & $12,092.33$ & $5,240.17$ \\
\hline E2 & M3 & $43,888.89 *$ & 301.50 & $11,940.86$ & $5,511.96$ \\
\hline \multicolumn{2}{|l|}{$\mathrm{T} 1$} & $56,277.77$ & 270.07 & $10,820.63$ & $8,672.21$ \\
\hline \multicolumn{2}{|c|}{ F value - factorial $\mathrm{x}$ control } & $4.52 *$ & $0.62^{\text {ns }}$ & $0.0379^{\mathrm{ns}}$ & $2.88^{\mathrm{ns}}$ \\
\hline \multicolumn{2}{|l|}{ LSD } & $12,352.03$ & 34.02 & 298.04 & $2,783.93$ \\
\hline \multicolumn{2}{|l|}{$\mathrm{CV}(\%)$} & 12.50 & 6.24 & 13.79 & 18.67 \\
\hline
\end{tabular}

Treatment averages followed by ${ }^{\mathrm{ns}}$ or by no letters, in the columns, do not differ from the control, by the Dunnet test. Treatment averages followed by * are significantly different $(\mathrm{p}<0.05)$ from the control treatment. E1 - $0.45 \mathrm{~m}$ spacing; E2 - $0.90 \mathrm{~m}$ spacing; M1 - Urochloa ruziziensis sown in the row with maize seeding; M2 - Urochloa ruziziensis sown by hauling along the maize seeding; M3 - Urochloa ruziziensis sown by hauling, when maize reached the V4 growth stage; T1 - control spaced at $0.45 \mathrm{~m}$; LSD - least significant difference. 
Table 4. Mean value for final density, 1,000-grain weight and grain yield, when compared to the control at $0.90 \mathrm{~m}$ spacing.

\begin{tabular}{|c|c|c|c|c|c|}
\hline \multicolumn{2}{|c|}{ Variable } & \multirow{2}{*}{ 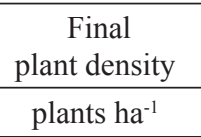 } & \multirow{2}{*}{$\begin{array}{c}\begin{array}{c}\text { 1,000-grain } \\
\text { weight }\end{array} \\
\mathrm{kg}\end{array}$} & $\begin{array}{l}\text { Grain } \\
\text { yield }\end{array}$ & \multirow{2}{*}{$\begin{array}{c}\text { Maize } \\
\text { dry matter } \\
\end{array}$} \\
\hline Spacing & Method & & & $\mathrm{kg} \mathrm{ha}^{-1}$ & \\
\hline E1 & M1 & $51,111.11^{*}$ & 267.90 & $9,485.46$ & $9,657.37$ \\
\hline E1 & M2 & $54,833.33^{*}$ & 270.59 & $9,652.31$ & $8,157.00$ \\
\hline E1 & M3 & $60,777.77 *$ & 254.29 & $10,627.82$ & $9,171.54$ \\
\hline $\mathrm{E} 2$ & M1 & $43,055.55^{\mathrm{ns}}$ & 286.56 & $12,078.90$ & $6,527.72$ \\
\hline E2 & M2 & $40,833.33^{\text {ns }}$ & 283.58 & $12,092.33$ & $5,240.17$ \\
\hline E2 & M3 & $43,888.89^{\mathrm{ns}}$ & 301.50 & $11,940.86$ & $5,511.96$ \\
\hline \multicolumn{2}{|l|}{$\mathrm{T} 2$} & $40,833.33$ & 295.70 & $11,953.61$ & $6,727.08$ \\
\hline \multicolumn{2}{|c|}{$\mathrm{F}$ value - factorial $\mathrm{x}$ control } & $6.8481 *$ & $4.035^{\mathrm{ns}}$ & $1.42^{\mathrm{ns}}$ & $0.61^{\text {ns }}$ \\
\hline \multicolumn{2}{|l|}{ LSD } & $11,510.61$ & 33.25 & $2,984.52$ & $3,044.84$ \\
\hline \multicolumn{2}{|l|}{$\mathrm{CV}(\%)$} & 12.19 & 6.02 & 13.61 & 21.20 \\
\hline
\end{tabular}

Treatment averages followed by ${ }^{\mathrm{ns}}$ or by no letters, in the columns, do not differ from the control, by the Dunnet test. Treatment averages followed by $*$ are significantly different $(\mathrm{p}<0.05)$ from the control treatment. E1 - $0.45 \mathrm{~m}$ spacing; E2 - $0.90 \mathrm{~m}$ spacing; M1 - Urochloa ruziziensis sown in the row with maize seeding; M2 - Urochloa ruziziensis sown by hauling along the maize seeding; M3 - Urochloa ruziziensis sown by hauling, when the maize reached the V4 growth stage; T1- control spaced at $0.90 \mathrm{~m}$; LSD - least significant difference.

$0.45 \mathrm{~m}$ spacing, if compared to the control spaced at $0.90 \mathrm{~m}(\mathrm{~T} 2)$, regardless of seeding method. These results demonstrate that spacing is a decisive factor to the number of effectively established plants.

Grain yield and maize dry matter contents were similar for intercropping systems and controls, indicating that the intercropping between maize and Urochloa ruziziensis is feasible and do not interfere with the maize production.

\section{CONCLUSIONS}

1. Grain yield is higher for the $0.90 \mathrm{~m}$ spacing between maize rows.

2. Intercropping between maize and Urochloa ruziziensis preserves agronomic characteristics, grain yield and dry matter content of both species.

3 . The dry matter content produced is satisfactory for maintaining the no-tillage system in all treatments evaluated, with higher maize biomass yield for the $0.45 \mathrm{~m}$ spacing.

\section{REFERENCES}

ALVARENGA, R. C. et al. A cultura do milho na integração lavoura-pecuária. Sete Lagoas: Embrapa Milho e Sorgo, 2006.

ANDRIOLI, I.; CENTURION, J. F. Levantamento detalhado dos solos da Faculdade de Ciências Agrárias e Veterinárias de Jaboticabal. In: CONGRESSO
BRASILEIRO DE CIÊNCIA DO SOLO, 27., 1999, Brasília, DF. Anais... Brasília, DF: Sociedade Brasileira de Ciência do Solo, 1999. p. 1-4.

ARGENTA, G.; SILVA, P. R. F. D.; SANGOI, L. Arranjo de plantas em milho: análise do estado-da-arte. Ciência Rural, v. 31, n. 6, p. 1075-1084, 2001.

BALBINOT JUNIOR, A. A.; FLECK, N. G. Manejo de plantas daninhas na cultura de milho em função do arranjo espacial de plantas e características dos genótipos. Ciência Rural, v. 34, n. 6, p. 245-252, 2004.

BALBINOT JUNIOR, A. A. et al. Integração lavourapecuária: intensificação de uso de áreas agrícolas. Ciência Rural, v. 39, n. 6, p. 1925-1933, 2009.

BATISTA, K. et al. Acúmulo de matéria seca e de nutrientes em forrageiras consorciadas com milho safrinha em função da adubação nitrogenada. Pesquisa Agropecuária Brasileira, v. 46, n. 10, p. 1154-1160, 2011.

BORGHI, E.; CECCON, G.; CRUSCIOL, C. A. C. Manejo de espécies forrageiras em consórcio com milho safrinha. In: SEMINÁRIO NACIONAL DE MILHO SAFRINHA, 12., 2013, Dourados. Anais... Dourados: Embrapa Agropecuária Oeste, 2013. p. 1-14.

BORGHI, E. et al. Influência da distribuição espacial do milho e da Brachiaria brizantha consorciados sobre a população de plantas daninhas em sistema plantio direto na palha. Planta Daninha, v. 26, n. 3, p. 559-568, 2008.

BORGHI, E.; CRUSCIOL, C. A. C. Produtividade de milho, espaçamento e modalidade de consorciação com Brachiaria brizantha em sistema plantio direto. Pesquisa Agropecuária Brasileira, v. 42, n. 2, p. 163-171, 2007. 
BRASIL. Ministério da Agricultura e Reforma Agrária. Regras para análise de sementes. Brasília, DF: SNDA/ DNPV/CLAV, 1992.

CALONEGO, J. C. et al. Produtividade e crescimento de milho em diferentes arranjos de plantas. Agrarian, v. 4, n. 1, p. 84-90, 2011.

CHIODEROLI, C. A. et al. Desempenho de semeadoraadubadora em função do preparo de solo e espaçamento da cultura do milho. Pesquisa Agropecuária Tropical, v. 40, n. 4, p. 462-467, 2010.

COMPANHIA NACIONAL DE ABASTECIMENTO (Conab). Acompanhamento da safra brasileira de grãos: safra 2015/16, $6^{\circ}$ levantamento. 2016. Available at: $<$ http:// www.conab.gov.br>. Access on: 28 Mar. 2016.

CORREIA, N. M.; LEITE, M. B.; FUZITA, W. E. Consórcio de milho com Urochloa ruziziensis e os efeitos na cultura da soja em rotação. Bioscience Journal, v. 29, n. 1, p. 65-76, 2013.

COSTA, A. S. V. et al. Densidades populacionais de milho na região do Vale do Rio Doce. Ceres, v. 52, n. 299, p. 3344, 2005.

COSTA, N. R. et al. Adubação nitrogenada no consórcio de milho com duas espécies de braquiária em sistema plantio direto. Pesquisa Agropecuária Brasileira, v. 47, n. 8, p. 1038-1047, 2012.

DIAS, V. O. et al. Distribuição de sementes de milho e soja em função da velocidade e densidade de semeadura. Ciência Rural, v. 39, n. 6, p. 1721-1728, 2009.

EMPRESA BRASILEIRA DE PESQUISA AGROPECUÁRIA (Embrapa). Nutrição e adubação do milho. 2006. Available at: < http://www.cnpms.embrapa. br/publicacoes/publica/2006/circular/Circ_78.pdf>. Access on: 15 Jan. 2015.

EMPRESA BRASILEIRA DE PESQUISA AGROPECUÁRIA(Embrapa). Cultivo do milho: manejo de solos. 2010. Available at: $<$ http://www.cnpms.embrapa. br/publicacoes/milho_6_ed/ferorganica.htm $>$. Access on: 05 Jun. 2015.
EMPRESA BRASILEIRA DE PESQUISA AGROPECUÁRIA (Embrapa). Cultivo do milho: apresentação. 2012. Available at: <http://www.cnpms. embrapa.br/publicacoes/milho_8_ed/index.htm $>$. Access on: 14 Jun. 2015.

FREITAS, R. J.; NASCENTE, A. S.; SANTOS, F. L. S. População de plantas de milho consorciado com Urochloa ruziziensis. Pesquisa Agropecuária Tropical, v. 43, n. 1, p. 79-87, 2013.

MONTGOMERY, D. C. Introdução ao controle estatístico da qualidade. 4. ed. Rio de Janeiro: LTC, 2004.

PEREIRA FILHO, I. A.; ALVARENGA, R. C.; CRUZ, J. C. Fatores que interferem no resultado do milho. Campo e Negócio, v. 5, n. 68, p. 24-27, 2008.

RIBAS, M. R. et al. Competição de híbridos de milho com plantas daninhas em dois espaçamentos entrelinhas. Global Science and Technology, v. 6, n. 2, p. 38-47, 2013.

RITCHIE, S. W.; HANWAY, J. J.; BENSON, G. O. Como a planta de milho se desenvolve. 2003. Available at: <http://brasil.ipni.net/ipniweb/region/brasil.nsf/0/ DE02520B8765B8D683257AA0003C46A6/\$FILE/ Encarte103.pdf $>$. Access on: 13 Jun. 2015.

SANGOI, L. et al. Rendimento de grãos, produção e distribuição de massa seca de híbridos de milho em função do aumento da densidade de plantas. Current Agricultural Science and Technology, v. 11, n. 1, p. 25-31, 2005.

SCHIMANDEIRO, A. et al. Distribuição longitudinal de plantas de milho (Zea mays L.) na região dos Campos Gerais, Paraná. Ciência Rural, v. 36, n. 3, p. 977-980, 2006.

STACCIARINI, T. D. C. V. et al. Avaliação de caracteres agronômicos da cultura do milho mediante a redução do espaçamento entre linhas e aumento da densidade populacional. Ceres, v. 57, n. 4, p. 516-519, 2010.

TORRES, F. E. et al. Desempenho de híbridos de milho cultivados em diferentes espaçamentos na região do Cerrado brasileiro. Revista de Ciências Agrárias, v. 36, n. 4, p. 411-416, 2013. 